\title{
Benzo[de]naphtho[1,8-gh]quinolines: synthesis, photophysical studies and nitro explosives detection
}

\author{
Igor L. Nikonov ab* (D), Igor A. Khalymbadzha a, Leila K. Sadieva a, \\ Maria I. Savchuk ${ }^{\text {ab }}$, Ekaterina S. Starnovskaya ${ }^{a b}$, Dmitry S. Kopchuk ${ }^{\text {ab }}$ (D), \\ Igor S. Kovalev ${ }^{\text {a }}$, Grigory A. Kim ${ }^{\text {b }}$, Oleg N. Chupakhin ${ }^{\text {ab }}$
}

a: Ural Federal University, 620002 Mira st., 19, Yekaterinburg, Russia

b: I.Ya. Postovsky Institute of Organic Synthesis of the Ural Branch of the RAS, 620990 Kovalevskoy/Akademicheskaya st., 22/20, Yekaterinburg, Russia

* Corresponding author: igor.nikonov.ekb@gmail.com

This article belongs to the regular issue.

(C) 2021, The Authors. This article is published in open access form under the terms and conditions of the Creative Commons Attribution (CC BY) license (http://creativecommons.org/licenses/by/4.o/).

\section{Abstract}

A rational synthetic approach to substituted naphtho[1,8$g h$ ]quinolines based on intramolecular cyclization in the presence of potassium in the series of (naphthalen-1-yl)isoquinolines is described. The photophysical properties of the obtained compounds were studied; in particular, fluorescence emission was detected in the range $454-482 \mathrm{~nm}$ with a quantum yield of up to $54 \%$. We also calculated the HOMO-LUMO energies and optimized molecular structures for the resulting fluorophores. Based on the results of fluorescence titration, the Stern-Volmer constants (up to $21587 \mathrm{M}^{-1}$ ) and the detection limits of nitroanalytes (up to $1.4 \mathrm{ppm}$ ) were calculated, confirming the possibility of their use as potential chemosensors for the visual detection of nitro-containing explosives.

\section{Keywords}

benzo[de]naphtha

$[1,8-$ gh $]$ quinolones

fluorescence

sensor

explosives

Received:15.12.2021

Revised: 20.12.2021

Accepted: 20.12.2021

Available online: 23.12 .2021

\section{Introduction}

Annelated polyaromatic compounds represent a wide class of organic substances that are widely used as chemosensors, including ones for the detection of nitro explosives. Naphthalene and its aryl-annelated derivatives, such as phenanthrene, triphenylene, pyrene, dibenzoanthracene, gelcenes, etc. are typical chemosensors for nitroanalytes [1]. Perylene deserves special attention in this series due to the interesting photophysical properties, as well as a sensory response to some nitroaromatic compounds, for example, picric acid [2-5]. Meanwhile, the introduction of a pyridine nitrogen atom into the structure of polycyclic aromatic hydrocarbons can be useful for creating more efficient chemosensors by combining $\pi$-excess receptor and fluorophore fragments into one molecule and enhancing the receptor properties, for example, in relation to nitro-analytes, by creating $\pi$-conjugated donor-acceptor ensembles [1]. It should be noted that aza analogs of perylene often have promising fluorescent characteristics, as well as higher LUMO energies values, which may determine the greater ability of azaperylenes to detect nitro explosives, including aliphatic ones $[6,7]$.
However, a more detailed study of the photophysical and chemosensory properties of these fluorophores has not been found in the literature. In this regard, we would like to present a method for obtaining new fluorophores of the benzo[de]naphtho[1,8-gh]quinoline series and an investigation of their sensory response to some nitroanalytes.

\section{Experimental}

${ }^{1} \mathrm{H}$ NMR spectra were recorded on a Bruker Avance-40o spectrometer ( $400 \mathrm{MHz}$ ), the internal standard was $\mathrm{SiMe}_{4}$. Mass-spectra (ionization type - electrospray) were recorded on a MicrOTOF-Q II instrument from Bruker Daltonics (Bremen, Germany). Elemental analysis was performed on a Perkin Elmer PE 2400 II CHN analyzer. HOMO-LUMO and optimized molecular structures calculations of compounds were carried out in the Orca 4.0.1 software package using the DFT B3LYP, 6-311G* method [8]. UV-visible absorption spectra were recorded on a Perkin Elmer Lambda 45. Luminescence spectra were obtained using a HORIBA Scientific FluoroMax-4 spectrofluorometer. The starting 2-(methoxyphenyl)ethanamines 4, 1-naphthoyl chloride, and all reagents were obtained from commercial sources. 


\subsection{General procedure for the synthesis of $\mathrm{N}$-(methoxyphenethyl)-1-naphthamides 2}

To an ice cooled solution of the corresponding 2-(methoxyphenyl)ethanamine 4 (10.0 $\mathrm{mmol}$ ) (in case of compound $4 \mathrm{~b}$ oxalate was used) and 1-naphthoyl chloride $(2.09 \mathrm{~g}, 11.0 \mathrm{mmol})$ in dichloromethane $(20 \mathrm{~mL})$ was added diisopropylethylamine $(2.84 \mathrm{~g}, 22.0 \mathrm{mmol})$. The mixture was stirred for $12 \mathrm{~h}$, poured in ice and the product was extracted with dichloromethane. The organic layer was washed with water, dried with anhydrous $\mathrm{Na}_{2} \mathrm{SO}_{4}$ and evaporated to obtain $N$-(4-dimethoxyphenethyl)-1naphthamide as white solid.

N-(4-Methoxyphenethyl)-1-naphthamide (2a). Yield $2.47 \mathrm{~g}(81 \%) .{ }^{1} \mathrm{H}$ NMR (40O MHz, DMSO-d $\left.6, \delta, \mathrm{ppm}\right)$ : $8.36(b r s, 1 \mathrm{H}), 8.09(d, J=7.9 \mathrm{~Hz}, 1 \mathrm{H}), 7.88-7.93(m$, $2 \mathrm{H}), 7.46-7.5 \mathrm{O}(m, 4 \mathrm{H}), 7.19(d, J=8.1 \mathrm{~Hz}, 1 \mathrm{H}), 6.83(d$, $J=8.1 \mathrm{~Hz}, \quad 1 \mathrm{H}), \quad 3.77 \quad(s, \quad 3 \mathrm{H}), \quad 3.52-3.57 \quad(m, \quad 2 \mathrm{H})$, 2.84-2.89 $(m, 2 \mathrm{H})$. ESI-MS, $m / z: 306.14[\mathrm{M}+\mathrm{H}]^{+}$. Found, \%: C 78.58, H 6.24, N 4.64. $\mathrm{C}_{20} \mathrm{H}_{19} \mathrm{NO}_{2}$. Calculated, \%: C 78.66, H 6.27, N 4.59.

$\mathrm{N}$-(3,4-Dimethoxyphenethyl)-1-naphthamide

(2b). Yield $2.71 \mathrm{~g}(77 \%) .{ }^{1} \mathrm{H}$ NMR (400 $\left.\mathrm{MHz}, \mathrm{CDCl}_{3}, \delta, \mathrm{ppm}\right)$ : 8.20-8.22 ( $m, 1 \mathrm{H}), 7.84-7.90(m, 2 \mathrm{H}), 7.50-7.53(m, 3 \mathrm{H})$, $7.40-7.44(m, 1 \mathrm{H}), 6.79-6.83(m, 3 \mathrm{H}), 5.98($ br $s, 1 \mathrm{H})$, $3.86(s, 3 \mathrm{H}), 3.82-3.78(m, 5 \mathrm{H}), 2.94-2.97(m, 2 \mathrm{H})$. ${ }^{1} \mathrm{H}$ NMR in DMSO is in accordance with published data [9]. ESI-MS, $m / z: 336.15[\mathrm{M}+\mathrm{H}]^{+}$. Found, \%: C 75.24, H 6.37, $\mathrm{N}$ 4.14. $\mathrm{C}_{21} \mathrm{H}_{21} \mathrm{NO}_{3}$. Calculated, \%: C 75.20, H 6.31, N 4.18.

\subsection{General procedure for the synthesis of 1-(naphthalen-1-yl)-3,4-dihydroisoquinolines (3a,b)}

To a solution of the corresponding $\mathrm{N}$-(4methoxyphenethyl)-1-naphthamide $2(6.56 \mathrm{mmol})$ in dry toluene $(30 \mathrm{ml})$ was added freshly distilled $\mathrm{POCl}_{3}(5.03 \mathrm{~g}$, $32.8 \mathrm{mmol}$ ). The mixture was stirred at $110{ }^{\circ} \mathrm{C}$ for $8 \mathrm{~h}$, poured into ice. Water solution of $\mathrm{NaOH}$ was added until $\mathrm{pH}>10$ was adjusted. The product was extracted with dichloromethane $(3.30 \mathrm{~mL})$. The organic layers were combined, dried and evaporated yielding crude 3,4dihydroisoquinoline.

7-Methoxy-1-(naphthalen-1-yl)-3,4-dihydroisoquinoline (3a). Off-white solid. Yield $1.11 \mathrm{~g},(59 \%)$. ${ }^{1} \mathrm{H}$ NMR (6oo $\left.\mathrm{MHz}, \mathrm{CDCl}_{3}, \delta, \mathrm{ppm}\right): 7.91(d d, J=5.6 \mathrm{~Hz}, J=4.0 \mathrm{~Hz}, 1 \mathrm{H})$, $7.88(d, 7.9 \mathrm{~Hz}, 1 \mathrm{H}), 7.73(d d d, J=8.5 \mathrm{~Hz}, J=1.0 \mathrm{~Hz}$, $J=1.0 \mathrm{~Hz}, 1 \mathrm{H}), 7.53(d, J=2.0 \mathrm{~Hz}, 1 \mathrm{H}), 7.53(\mathrm{~s}, 1 \mathrm{H})$, $7.46(d d d, J=8.1 \mathrm{~Hz}, J=6.8 \mathrm{~Hz}, J=1.2 \mathrm{~Hz}, 1 \mathrm{H})$, $7.37(d d d, J=8.2 \mathrm{~Hz}, J=6.8 \mathrm{~Hz}, J=1.3 \mathrm{~Hz}, 1 \mathrm{H})$, $7.22(d, J=8.3 \mathrm{~Hz}, 1 \mathrm{H}), 6.91(d d, J=8.3 \mathrm{~Hz}, J=2.8 \mathrm{~Hz}$, $1 \mathrm{H}), 6.42(d, J=2.6 \mathrm{~Hz}, 1 \mathrm{H}), 4.02($ br $s, 2 \mathrm{H}), 3.55(s, 3 \mathrm{H})$, $2.90(m, 2 \mathrm{H})$. ESI-MS, $m / z: 288.13[\mathrm{M}+\mathrm{H}]^{+}$. Found, \%: C 83.67, H 6.o2, N 4.78. $\mathrm{C}_{20} \mathrm{H}_{17} \mathrm{NO}$. Calculated, \%: C 83.59, $\mathrm{H} 5.96, \mathrm{~N} 4.87$.

6,7-Dimethoxy-1-(naphthalen-1-yl)-3,4dihydroisoquinoline (3b). White solid. Yield $1.41 \mathrm{~g}$, (68\%).
${ }^{1} \mathrm{H}$ NMR in DMSO- $\mathrm{d}_{6}$ is in accordance with published data [10]. ESI-MS, $m / z: 318.14[\mathrm{M}+\mathrm{H}]^{+}$. Found, \%: C 79.43, $\mathrm{H}$ 6.12, $\mathrm{N}$ 4.34. $\mathrm{C}_{21} \mathrm{H}_{19} \mathrm{NO}_{2}$. Calculated, \%: C 79.47, $\mathrm{H}$ 6.03, $\mathrm{N} 4.41$.

\subsection{General procedure for the synthesis of 1-(naphthalen-1-yl)isoquinolines (1a,b)}

To a solution of the corresponding 1-(naphthalen-1-yl)-3,4dihydroisoquinoline $3(2.48 \mathrm{mmol})$ in benzene was added $\mathrm{MnO}_{2}$ (2.24 $\mathrm{g}, 25.8 \mathrm{mmol}$ ) and the mixture was stirred under reflux for 24 hours. Then mixture was cooled and $\mathrm{MnO}_{2}$ was filtered off, and benzene was evaporated to obtain isoquinoline.

7-Methoxy-1-(naphthalen-1-yl)isoquinoline (1a). Yield $0.60 \mathrm{~g}(85 \%)$. ${ }^{1} \mathrm{H}$ NMR (400 $\mathrm{MHz}, \mathrm{CDCl}_{3}, \delta, \mathrm{ppm}$ ): 8.60 $(d, J=5.6 \mathrm{~Hz}, 1 \mathrm{H}), 7.99(d d, J=6.2 \mathrm{~Hz}, J=3.5 \mathrm{~Hz}, 1 \mathrm{H})$, $7.95(d, J=8.3 \mathrm{~Hz}, 1 \mathrm{H}), 7.84(d, J=8.9 \mathrm{~Hz}, 1 \mathrm{H})$, $7.69(d, \quad J=5.6 \mathrm{~Hz}, \quad 1 \mathrm{H}), \quad 7.62-7.75 \quad(m, \quad 2 \mathrm{H})$, $7.49(d d, J=7.8 \mathrm{~Hz}, J=7.8 \mathrm{~Hz}, 1 \mathrm{H}), 7.45(d, J=8.2 \mathrm{~Hz}$, $1 \mathrm{H}), \quad 7.32-7.37(m, 2 \mathrm{H}), 6.88(d, J=2.6 \mathrm{~Hz}, 1 \mathrm{H})$, $3.56(s, 3 \mathrm{H})$. ESI-MS, $m / z: 286.12[\mathrm{M}+\mathrm{H}]^{+}$. Found, \%: C 84.15, H 5.32, N 4.94. $\mathrm{C}_{20} \mathrm{H}_{15} \mathrm{NO}$. Calculated, \%: C 84.19, $\mathrm{H} 5.30, \mathrm{~N} 4.91$.

6,7-Dimethoxy-1-(naphthalen-1-yl)isoquinoline (1b). Yield $731 \mathrm{mg}$ (90\%). ${ }^{1} \mathrm{H}$ NMR (400 $\left.\mathrm{MHz}, \mathrm{CDCl}_{3}, \delta, \mathrm{ppm}\right)$ : 8.56-8.57 ( $m, 1 \mathrm{H}), 7.93-8.00(m, 2 \mathrm{H}), 7.60-7.64(m, 3 \mathrm{H})$, $7.45-7.5 \mathrm{O}(m, 2 \mathrm{H}), 7.32-7.36(m, 1 \mathrm{H}), 7.17(s, 1 \mathrm{H})$, $6.85(s, 1 \mathrm{H}), 4.06(s, 3 \mathrm{H}), 3.59(s, 3 \mathrm{H})$. ESI-MS, $m / z$ : $316.13[\mathrm{M}+\mathrm{H}]^{+}$. Found, \%: C 80.06, H 5.39, N 4.47 . $\mathrm{C}_{21} \mathrm{H}_{17} \mathrm{NO}_{2}$. Calculated, \%: C 79.98, H 5.43, N 4.44 .

\subsection{General procedure for the synthesis of azaperylenes $(5 \mathrm{a}, \mathrm{b})$}

The corresponding 1-(naphthalen-1-yl)-isoquinoline 1 (1.05 mmol) was dissolved in dry toluene $(25 \mathrm{~mL})$; subsequently, potassium (10.5 mmol) was added under argon atmosphere. The resulting mixture was stirred at $95{ }^{\circ} \mathrm{C}$ for $6 \mathrm{~h}$, quenched with $i$-PrOH, filtered through silica gel, and the solvents were removed under reduced pressure. The residue was solved in ethyl acetate $(20 \mathrm{ml})$. The solution was washed with water $(3 \times 20 \mathrm{ml})$, the organic layer was dried over anhydrous $\mathrm{Na}_{2} \mathrm{SO}_{4}$ and evaporated under reduced pressure. The residue was purified by column chromatography (corresponding eluent). The crystallization $\left(\mathrm{CH}_{2} \mathrm{Cl}_{2} /\right.$ hexane) afforded pure product.

6-Methoxybenzo[de]naphtho[1,8-gh]quinoline (5a). Eluent: Hexane:i-PrOH=20:1, $R_{f}=0.9$. Yellow-green solids. Yield $99 \mathrm{mg}(33 \%) .{ }^{1} \mathrm{H} \mathrm{NMR}\left(400 \mathrm{MHz} \mathrm{CDCl}_{3}, \delta, \mathrm{ppm}\right)$ : $3.56(s, 3 \mathrm{H}), 7.35(d, J=7.2 \mathrm{~Hz}, 1 \mathrm{H}), 7.46-7.49(m, 2 \mathrm{H})$, $7.63(d, J=5.6 \mathrm{~Hz}, 1 \mathrm{H}), 7.85(d, J=8.9 \mathrm{~Hz}, 1 \mathrm{H})$, 7.94-8.02 $(m, \quad 2 \mathrm{H}), \quad 8.53 \quad(d, \quad J=6.8 \mathrm{~Hz}, \quad 1 \mathrm{H})$, $8.60(d, J=6.5 \mathrm{~Hz}, 1 \mathrm{H})$. ESI-MS, $m / z: 284,10[\mathrm{M}+\mathrm{H}]^{+}$. Found, \%: C 84.82, H 4.66, N 4.84. $\mathrm{C}_{20} \mathrm{H}_{13} \mathrm{NO}$. Calculated, $\%$ : C 84.78, H 4.62, N 4.94 .

5,6-Dimethoxybenzo[de]naphtho[1,8-gh]quinoline

(5b). Eluent: DCM:MeOH=100:1, $R_{f}=0.8$. Yellow-green 
solids. Yield $33 \mathrm{mg}(11 \%) .{ }^{1} \mathrm{H}$ NMR (40O $\mathrm{MHz}, \mathrm{CDCl}_{3}, \delta$, ppm): $4.22(s, 6 \mathrm{H}), 7.30(s, 1 \mathrm{H}), 7.43(d, J=7.8 \mathrm{~Hz}, 1 \mathrm{H})$, $7.59-7.62(t, J=8.0 \mathrm{~Hz}, 1 \mathrm{H}), 7.69(d, J=5.6 \mathrm{~Hz}, 1 \mathrm{H})$, $7.84(d, J=8.9 \mathrm{~Hz}, 1 \mathrm{H}), 7.93-7.99$ (m. $2 \mathrm{H}), 8.53$ ( $d$, $J=8.0 \mathrm{~Hz}, 1 \mathrm{H}), 8.58(d, J=7.5 \mathrm{~Hz}, 1 \mathrm{H})$. ESI-MS, $m / z$ : $314,11[\mathrm{M}+\mathrm{H}]^{+}$. Found, \%: C 80.56, H 4.74, N 4.50 . $\mathrm{C}_{21} \mathrm{H}_{15} \mathrm{NO}_{2}$. Calculated, \%: C 80.49, H 4.83, N 4.47 .

\section{Results and discussion}

The synthesis of the precursors of azaperylenes, methoxysubstituted (naphthalen-1-yl)isoquinolines 1, was carried out according to the previously described procedure [9] by cyclization of naphthamides $\mathbf{2}$ according to the BischlerNaperalsky procedure followed by oxidative dehydrogenation of intermediate 3 . While, precursor 2 was synthesized by amidation of 1-naphthoyl chloride with methoxysubstituted phenylethanamines 4 . Further, to obtain the target benzonaphthoquinolines $\mathbf{5}$, an attempt was made to use Lewis acid $\left(\mathrm{FeCl}_{3}\right)$ as an activator of the formation of a charge transfer complex, but this interaction did not allowed to obtain the target compounds 5. The use of cyclization in the presence of potassium [11] was more successfull. Thus, the starting isoquinoline 1 was kept in a solution of dry toluene at $95{ }^{\circ} \mathrm{C}$ in the presence of metallic potassium for $6 \mathrm{~h}$ (Scheme 1). The yields of mono- and dimethoxy-substituted azaperylenes 5 were $33 \%$ and $11 \%$, respectively, which is acceptable for reactions of this type $[6,11]$.

The obtained azaperylenes $\mathbf{5}$ demonstrated promising photophysical properties. The results are presented in Table 1. Thus, the absorption maximum for both fluorophores lies in the visible spectral region (441 nm), and the emission spectra contain two maxima lying in the green region (454-482 $\mathrm{nm}$ ), which is probably associated with the effect of intramolecular charge transfer (ICT). In addition, mono- and dimethoxy-substituted azaperylenes $\mathbf{5}$ demonstrated high luminescence quantum yields (54\% and $46 \%$ ).

Table 1 Photophysical properties of the obtained fluorophores 5

\begin{tabular}{|l|c|c|c|}
\hline Compound & $\lambda_{\text {abs }}, \mathrm{nm}$ & $\lambda_{\text {em }}, \mathrm{nm}$ & $\begin{array}{c}\text { Quantum } \\
\text { yield [12], \% }\end{array}$ \\
\hline 5a & $226,417,441$ & 457,482 & 54.0 \\
\hline 5b & 417,441 & 454,482 & 46.1 \\
\hline
\end{tabular}

The absorption and emission spectra of azaperylenes $\mathbf{5}$ in normalized form are presented in Fig. 1. For all compounds, the absorption/emission plots have a similar profile and represent a distorted specular reflection of each other.<smiles>[R]c1cc(CCCN)ccc1OC</smiles>

$\mathrm{R}=\mathrm{H}(\mathbf{a}), \mathrm{OMe}(\mathbf{b})$

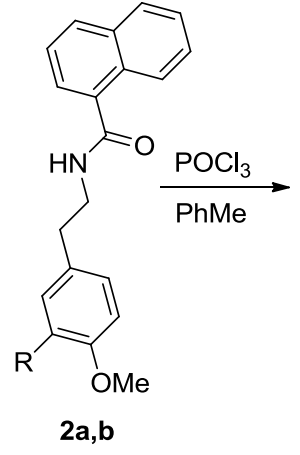

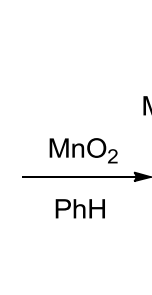

$3 a, b$<smiles>[R]c1cc2ccnc(-c3cccc4ccccc34)c2cc1OC</smiles>

$\mathrm{FeCl}_{3}$, r.t., $24 \mathrm{~h}$

Starting material

Scheme 1 Synthesis of benzo[de]naphtho[1,8-gh]quinolones

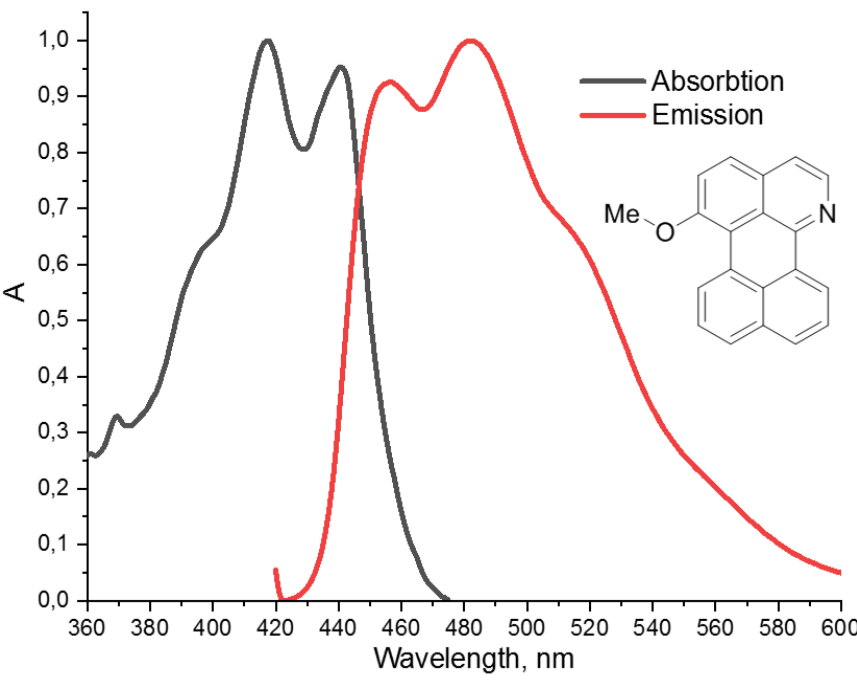

a)

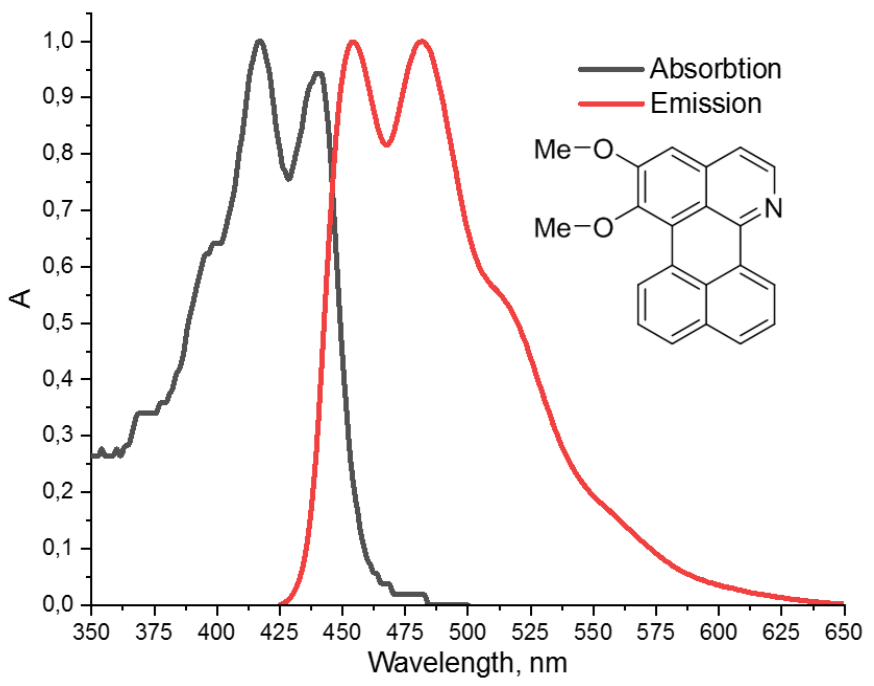

b)

Fig. 1 Normalized absorption/emission spectra of compounds $5 \mathrm{a}(\mathrm{a})$ and $5 \mathbf{b}$ (b) 
The above results of photophysical studies for azaperylenes $\mathbf{5}$ allowed predicting their use as potential fluorescent chemosensors for various nitro explosives. For the primary assessment of the efficiency of quenching the fluorescence of sensors under the action of nitroanalytes, the LUMO energy differences for the sensor and quencher corresponding to the thermodynamic driving force of this process were calculated $[1,7]$. Using the basic set DFT B3LYP, 6-311G*, the HOMO-LUMO energies were calculated and their optimized molecular structures [13-16] were obtained. The calculation results are shown in Table 2 . Compared to the previously calculated model of the HOMO/LUMO electronic configuration for unsubstituted perylene [17], the electron clouds of the obtained fluorophores are shifted to one degree or another relative to the nitrogen atoms of the azaperylene ring and methoxy groups, which indicates a high probability of intramolecular charge transfer processes. Calculations of LUMO values for three nitroanalytes, namely, RDX, DNT, and PETN, show that, in comparison with perylene, the obtained azaperylenes 5a,b are more capable of transferring an electron from the LUMO of azaperylene to the LUMO of these nitro compounds, which is expressed in the energy gap LUMO(sensor)-LUMO(quencher) from 0.3985 to $1.2409 \mathrm{eV}$, which should cause a "turn-off" fluorescent response.

A series of fluorescence quenching experiments were then performed by titrating the chemosensors 5 and perylene in acetonitrile solutions $\left(5 \cdot 10^{-5} \mathrm{M}\right)$ with solutions of RDX, DNT and PETN in acetonitrile $\left(5 \cdot 10^{-3} \mathrm{M}\right)$, as well as a solution of 2,4,6-trinitrophenol (picric acid) $\left(5 \cdot 10^{-4} \mathrm{M}\right)$ to confirm the results. It was found that an in- creasing PETN concentration does not cause fluorescence quenching for all of the considered sensors. In all likelihood, this can be caused by the low stability of the donor acceptor complex between these compounds and PETN. As for the other nitroanalytes, (RDX and DNT) in the case of dimethoxy-substituted azaperylene $\mathbf{5 b}$ and unsubstituted perylene fluorescence quenching was also practically not observed, and when these compounds were titrated with a solution of picric acid, the obtained Stern-Volmer constants do not exceed $4400 \mathrm{M}^{-1}$, which is an extremely low value in comparison with the literature data for other known chemosensors [1].

Opposite results were obtained when titrating monomethoxy-substituted sensor 5 a with solutions of RDX, DNT and picric acid. In this case, an increase in the concentration of nitroanalyte causes intense quenching of fluorescence. Thus, as a result of titration of 6methoxybenzo[de]naphtho[1,8-gh]quinoline $5 \mathrm{a}$ with a solution of picric acid, the obtained Stern-Volmer plot is linear, and the emission spectra of solutions before and after the addition of the analyte indicate almost complete quenching of the sensor fluorescence (Fig. 2). The obtained Stern-Volmer constants (853 $\mathrm{M}^{-1}$ (RDX), $1773 \mathrm{M}^{-1}$ (2,4-DNT), $21587 \mathrm{M}^{-1}$ (picric acid)) agree with the values described in the literature for most chemosensors for nitrous explosives [1].

In addition, based on the fluorescence titration data for azaperylene $\mathbf{5 a}$, the values of the limits of detection (LOD) of the nitroanalytes under consideration were calculated according to the described method [18]. The obtained LOD values are 22.4 ppm (RDX), 12.5 ppm (DNT), $1.4 \mathrm{ppm}$ (PA), which also corresponds to the literature data [1].

Table 2 Results of calculating the HOMO-LUMO energies and the driving force of fluorescence quenching of compounds $\mathbf{5}$ upon interaction with nitroanalytes

Structure




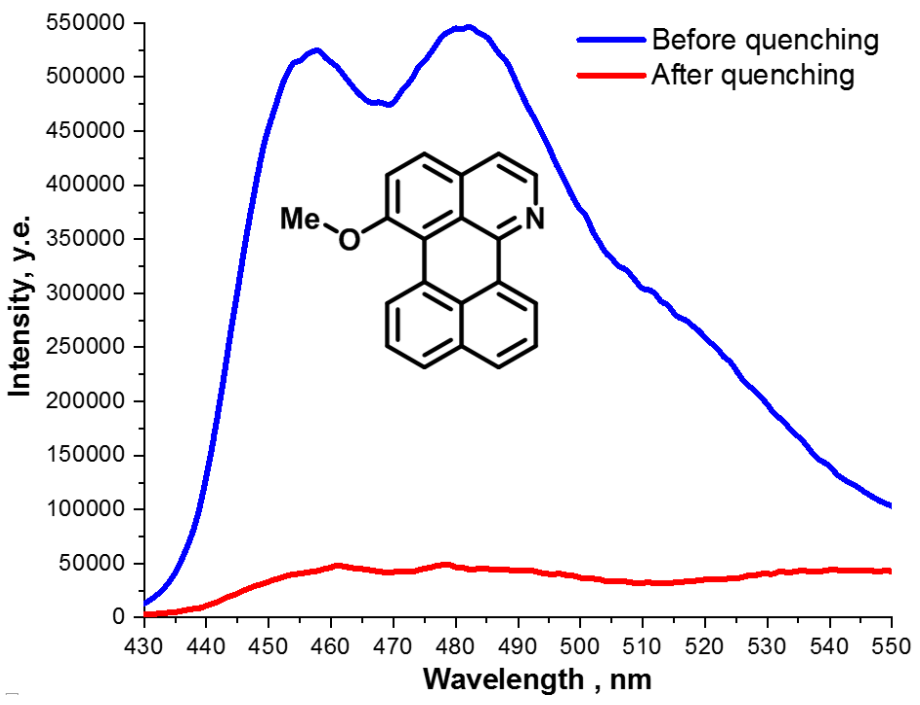

a)

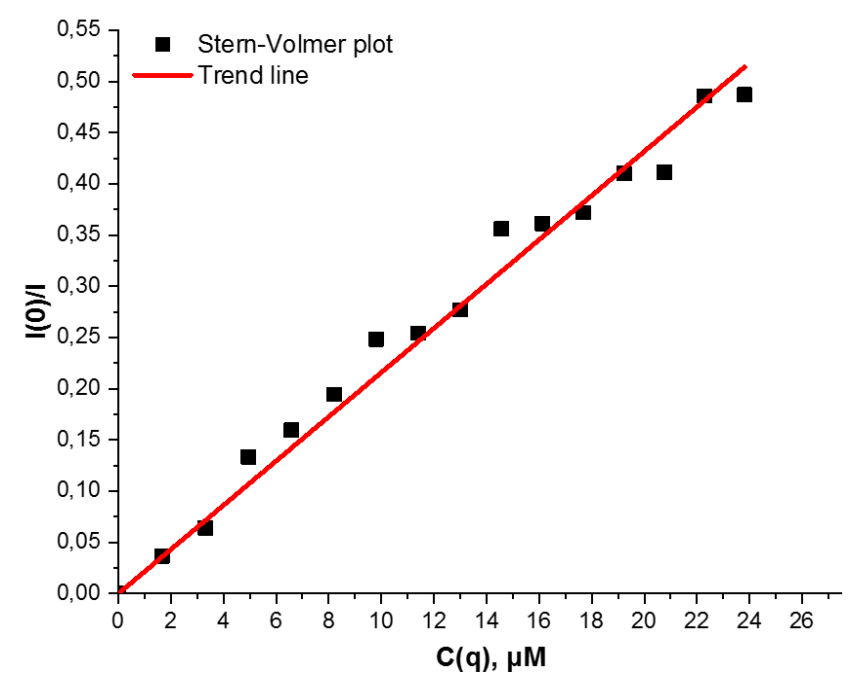

b)

Fig. 2 Fluorescence quenching of sensor 5a with picric acid solution: emission spectra (a) and Stern-Volmer plot (b)

\section{Conclusions}

Thus, we demonstrated a rational approach to obtaining new fluorophores with promising photophysical properties of naphtho[1,8-gh]quinolones series by cyclization of the corresponding (naphthalen-1-yl)isoquinolines in the presence of potassium. In addition, theoretical DFT calculations and fluorescence titration revealed the possibility of using these compounds as fluorescent chemosensors for visual detection of nitroaromatic explosives in solutions, as well as RDX.

\section{Acknowledgements}

This work was supported by the Grants Council of the President of the Russian Federation № NSh-2700.2020.3.

\section{References}

1. Zyryanov GV, Kopchuk DS, Kovalev IS, Nosova EV, Rusinov VL, Chupakhin ON. Chemosensors for detection of nitroaromatic compounds (explosives). Russ Chem Rev. 2014;83(9):783819. doi:10.1070/RC2014v083nogABEHoo4467

2. Lee JH, Rock JC, Schlautman MA, Carraway ER. Characteristics of key intermediates generated in uncatalyzed bis(2,4dinitrophenyl) oxalate (DNPO) chemiluminescence reactions. J Chem Soc, Perkin Trans. 2002;2:1653-7. doi:10.1039/b206367k

3. Pandey S, Fletcher KA, Powell JR, McHale MER, Kauppila ASM, Acree Jr WE, Fetzer JC, Dai W, Harvey RG. Spectrochim. Acta Part A. 1997;53:165-72.

4. Zhang P-F, Zeng J-C, Zhuang F-D, Zhao K-X, Sun Z-H, Yao Z-F, Lu Y, Wang X-Y, Wang J-Y, Pei J. Parent B2N2-perylenes with different BN orientations. Angew Chem Int Ed. 2021;60:23313-9. doi:10.1002/anie.202108519

5. Cui X, Zhao J, Yang P, Sun J. Zinc(II) tetraphenyltetrabenzoporphyrin complex as triplet photosensitizer for triplettriplet annihilation upconversion. Chem Commun. 2013;49:10221-3. doi:10.1039/c3cc45843a
6. Hirono A, Sakai H, Hasobe T. Synthesis and electrochemical and photophysical properties of azaterrylene derivatives. Chem Asian J. 2019;14:1754-62. doi:10.1002/asia.201801410 7. Harwell JR, Glackin JME, Davis NJLK, Gillanders RN, Credgington D, Turnbull GA, Samuel IDW. Sensing of explosive vapor by hybrid perovskites: effect of dimensionality. APL Mater. 2020;8:071106. doi:10.1063/5.0011229

8. Neese F. The ORCA program system. WIREs Comput Mol Sci. 2012;2:73-78. doi:10.1002/wcms.81

9. Tóth J, Dancsó A, Blaskó G, Tőke L, Groundwater PW, Nyerges M. 1,7-Electrocyclization reactions of stabilized $\alpha, \beta: \gamma, \delta$ unsaturated azomethine ylides. Tetrahedron. 2006;62:572535. doi:10.1016/j.tet.2006.03.088

10. Min L, Yang W, Weng Y, Zheng W, Wang X, Hu Y. A method for Bischler-Napieralski-type synthesis of 3,4dihydroisoquinolines. Org Lett. 2019;21(8):2574-7. doi:10.1021/acs.orglett.9bo0534

11. Gryko DT, Piechowska J, Gałęzowski M. Strongly emitting fluorophores based on 1-azaperylene scaffold. J Org Chem. 2010;75:1297-30. doi:10.1021/jog02443S

12. Porrès L, Holland A, Palsson L-O, Monkman AP, Kemp C, Beeby A. Absolute measurements of photoluminescence quantum yields of solutions using an integrating sphere. J Fluoresc. 2006;16:267-73. doi:10.1007/s10895-005-0054-8

13. Krishnan R, Binkley JS, Seeger R, Pople JA. Self-consistent molecular orbital methods. XX. A basis set for correlated wave functions. J Chem Phys. 1980;72:650-4. doi:10.1063/1.438955

14. McLean AD, Chandler J. GS. Contracted Gaussian basis sets for molecular calculations. I. Second row atoms, $Z=11-18$. Chem. Phys. 1980;72:5639-48. doi:10.1063/1.438980

15. Clark T, Chandrasekhar J, Schleyer PvR. Efficient diffuse function-augmented basis sets for anion calculations. III. The 3$21+\mathrm{G}$ basis set for first-row elements, Li-F. J Comp Chem. 1983;4:294-301. doi:10.1002/jcc.540040303

16. Frisch MJ, Pople JA, Binkley JS. Self-consistent molecular orbital methods 25. Supplementary functions for Gaussian basis sets. J Chem Phys. 1984;80:3265-9. doi: $10.1063 / 1.447079$

17. Mohamad M, Ahmed R, Shaari A, Goumri-Said S. Structure-dependent optoelectronic properties of perylene, di-indenoperylene (DIP) isolated molecule and DIP molecular crystal. Chem Cent J. 2017;11:125. doi:10.1186/s13065-017-0352-7

18. Shrivastava A, Gupta V. Methods for the determination of limit of detection and limit of quantitation of the analytical methods. Chronicles Young Sci. 2011;2:21. doi: $10.4103 / 2229-5186.79345$ 